\title{
Tech Dogma \# 2 : Libertarianism as founding ethos - The ballad of John Barlow
}

\author{
Camille Akmut
}

\begin{abstract}
After the claimed or superficial a-politicism of tech executives and various leaders presented in Tech Dogma \#1, we now turn to the dominant ideology of technology circles : Libertarianism. We look at one emblematic case - that of John Barlow, who came from the very upper fringes of society, went to India in the fashion typical of his class, and liked to play cattle rancher on his farm. These social origins later found their expressions in visions of an Internet and Web conceived as Libertarian space.
\end{abstract}


"Your grass is turning black

There's no water in your well

You spent your last lone dollar

On seven shotgun shells."

(Bob Dylan, The Ballad Of Hollis Brown)

"(...) and we'll leave it like that and tell you the story of Hollis Brown, what happens to him..."

(Nina Simone, "The Ballad Of Hollis Brown" Live in Holland 1965)

"It was always Marx, Lenin, and revolution - real girl's talk."

(Nina Simone, I Put a Spell on You: The Autobiography of Nina Simone) 


\section{Introduction}

Most of the following comes from the recently published autobiography of John Barlow ${ }^{1}$. To Libertarian visions of the Internet and Web correspond upper-class origins and various acts denoting them.

\section{Among the 1\%, there are no classes}

In highly euphemistic terms - they too typical of his class of origin Barlow describes nonetheless what are objectively the (structures of the) upper classes, of which he came from :

"Wyoming is a one-class state, and if you think you're better than someone else, they will tell you to your face that you're wrong. My mother, Miriam Jenkins Barlow, would have argued this point with you because, to the extent that there is aristocracy in that part of the world, she was kind of like Wyoming royalty.

Her great-uncle was a cattle baron named Amos Smith, who was the first human being to spend a winter in the high reaches of the upper Green River basin. Not even the Indians had ever tried to do that

(...)

I imagine it was a lot like what Hugh Glass, who was my hero when I was about seven years old, went through in The Revenant

(...)

These were pioneering ideas, and so he hired a bunch of people to homestead for him on 160 acres" $^{2}$

In this first chapter, long-winded descriptions of illustrious ancestors go on and on, we don't include them here, denoting regularly a fixation with their various status symbols (in particular scholarly titles, and their related institutions).

This self-stylized rebel remained true to his origins including right up to the end, when he finally looked back on them.

\section{Typical bourgeois rebellions}

The offspring of the upper-classes, being able to fall back on their families at the first sign of trouble, usually go through short-lived rebellions : drugs, sex, parties, etc. - this book so full of them, we could quote from any page at random.

Shortly after I arrived at Wesleyan in the fall of 1965 I went to a mixer at Vassar College. A dapper Indian fellow was hitting on all the girls (...) the next thing I knew, I was at the Castalia

${ }^{1}$ Mother American Night.

${ }^{2}$ Ch. 1. 
Foundation, which was what Timothy Leary was then calling the group of people who were living communally with him and taking LSD together. (...) Music was playing and people were walking around, some of them high on acid. ${ }^{3}$

Much of the rest of the book is like this, and pointless.

\section{Trip to India, just like St. John}

Then comes the obligatory trip to India - just like St. John had done in Bronte's novel.

I encountered many other hippies on the road; they were pretty common there in those days. Many of them were English and had become highly susceptible to shedding all their Western trappings, putting on dhotis, and wandering across the plains. ${ }^{4}$

He himself seems to have some confused understanding of his situation.

\section{Matching ideology : Libertarianism}

If the biography of John Barlow is not lacking in one thing, then the constant references to the (federal) government, and land, and acres, and control thereof.

Alan Simpson, an old family friend who was about to be elected to the U.S. Senate from Wyoming, said, "I've got a guy here I want you to meet and consider working for. (...) Dick Cheney does know how to deal with the federal government. He can play fuck 'em with anybody in Washington, D.C., and he cares just as much about protecting Wyoming as you do." That was precisely what I wanted in a state where 78 percent of the land was controlled by the federal government, which meant that somebody other than the people who lived there were in charge and rarely making decisions that anybody there agreed with.

(...) Dick Cheney is one of the two smartest men I've ever met, the other being Bill Gates. ${ }^{5}$

Dick Cheney who was Secretary of Defense under Bush then Vice President under Bush Jr., a "strong advocate" of the Iraq War in his own words, from which he made a 'killing' with company Halliburton (CEO).

Barlow must have not known many smart people, neither was he.

\footnotetext{
${ }^{3}$ Ch. 6.

${ }^{4}$ Ch. 12 .

${ }^{5}$ Ch. 22 .
} 


\section{Conclusion}

An imagined American frontier (minus the details of what happened to the Native Americans), cattle ranches and cowboys, no government and no taxes, family connections to politics, typical bourgeois rebellions found in drugs, trips to faraway, exotic or oriental lands, male-centric conquests... Such is the ballad of John Barlow (that could have been written by Dylan).

And, we wish we could claim no knowledge of the Grateful Dead, figuring its lyrics to be full of the same fantasies and false ideals.

"I was born in the desert, raised in a lion's den / My number one occupation is stealing women from their men / I'm a wanted man in Texas (...) / a couple shots of whiskey [and] women around here start looking good" 6

Grateful, we can conclude these pages by having not much more knowledge of these records, and proudly can say to know those of Bob Dylan, Nina Simone instead.

For we know the latter to be of much greater use to us - the rest of us.

One can only do so much with the mind fictions of the $1 \% \ldots$ and that is less than $1 \%$. No amount of money could ever give them right minds.

"Governments of the Industrial World, you weary giants of flesh and steel, I come from Cyberspace..."7

Equally we know these lines to not have come from one who was from the people.

And, so we must ask : liberation or "shakedown"? Impasse?

It has hopefully not escaped anyone either that while the word "government" opens and closes this manifesto of Libertarian inspiration, in it companies are nowhere to be found. But, only because in Barlow's vision they were everywhere, unproblematic.

"We don't come from the same planet" said Michel Foucault in a damning passage, an infinitely greater thinker. We don't - neither from the same space.

\footnotetext{
6 "All New Minglewood Blues", Shakedown Street (1978).

${ }^{7}$ Barlow 1996.
} 


\section{REFERENCES}

—. 2019. "Tech dogma \# 1: The Great Separation, between the "technical" and the "political". Documents towards a history."

Barlow, John. 1996. A Declaration of the Independence of Cyberspace. https://www.eff.org/cyberspace-independence

—. 2018. Mother American Night: My Life in Crazy Times. Crown Archetype.

The complete annotated Grateful Dead lyrics : the collected lyrics of Robert Hunter and John Barlow. Free Press. 